\title{
The Relationship between Product Quality, E-Service Quality and Brand Image on Customer Satisfaction: Preliminary Investigation in Perlis
}

\author{
Lee Sze Yuan ${ }^{1}$, Muhammad Shahar Jusoh, PhD', Dayang Hasliza Muhd Yusuf, PhD ${ }^{3}$ and \\ Mohd Rosli Abdul Ghani ${ }^{4}$ \\ ${ }^{1}$ Faculty of Applied and Human Sciences, Universiti Malaysia Perlis, Kangar, Perlis
}

\begin{abstract}
This study focusing on The Effect of Product Quality, E-Service Quality and Brand Image on Customer Satisfaction which focusing among Perlis's online shopping. The sample comprised of 250 online consumers at Perlis. The sampling method used in this research is the random method. The questionnaires were distributed by using google form. The data collected was analyzed by using software named as IBM Statistical Package for the Social Sciences (SPSS) version 25. The findings presented that product quality $(\beta=.213, \mathrm{p}=.001)$, e-service quality $(\beta=.142, \mathrm{p}=.039)$ and brand image $(\beta=.553, \mathrm{p}=.000)$ are the factors that significantly related to customer satisfaction. The analytical results confirmed that there is a significant positive correlation between product quality, e- service quality and brand image and online customer satisfaction. The study involves some management implications. In addition to this, the study has some limitations. Therefore, some suggestions are put forward for future research.
\end{abstract}

Key words: Product Quality (PQ), E-Service Quality (SQ), Brand Image (BI), Customer Satisfaction (CS)

\section{INTRODUCTION}

The online market or e-commerce has seen remarkable development in recent years in today's unstable global economy. The online shopping industry in Malaysia is projected to rise to more than RM 1.9 billion in 2016 (Dynamics et al., 2014). To remain competitive, online businesses need to understand how to respond to customer needs effectively. Consequently, customers are becoming increasingly relevant, which is an integral element in purchasing merchandise online. Thus understanding customer satisfaction has been one of the key elements of growth in e-commerce (Zendehdel et al., 2015).

In order to influence the productivity of the business, customer satisfaction is increasingly critical. Internet consumers are seeking a higher standard of service efficiency relative to traditional channel consumers. Otherwise, the e-commerce platform Customer to Consumer (C2C) will enable customers easily transition into other online retailers. It is especially necessary to utilize all available tools to enhance service quality and customer satisfaction and maintain consumer loyalty (Garg, 2018).
Previous study has shown that customers are more likely to express their experience with others when they are satisfied with a product or service (Musa et al., 2015). Companies also ought to recognize customer satisfaction as it would maintain customer loyalty and attract new consumers (Guo et al., 2012). There are several main variables that decide customer satisfaction, so online companies should be well updated to match the customer satisfaction antecedents of the company (Guo et al., 2012). When such aspects are known, customer satisfaction can increase, thereby increasing profitability of the company.

Online stores have offline characteristics of product quality. Product quality is essential for e-commerce in order to sustain customer satisfaction and to reduce the danger and costs associated with substituted faulty goods. When the consistency of the company's products is low, customers do not buy it. Especially if customers find similar products at a lower price and better quality in the e-commerce market, they can easily purchase and buy from more flexible competitors (Lin et al., 2011).

Lim et al., (2016) described the internet-based services have achieved significant growth in recent years. When buying the same product in each store, 
there will be different experiences on the online platform, depending on how they show the product to potential customers. Provide customers with time limits and infinite options. The reason for measuring service quality and the gaps is the provision of customer satisfaction information. Business management must consider how customers interpret and assess web applications in order to increase service quality. As the Internet and enterprise globalization exponentially grow, the retail industry is increasingly competitive and efficient (Garg, 2018).

\section{Figure 1.1: Reasons for returning products}

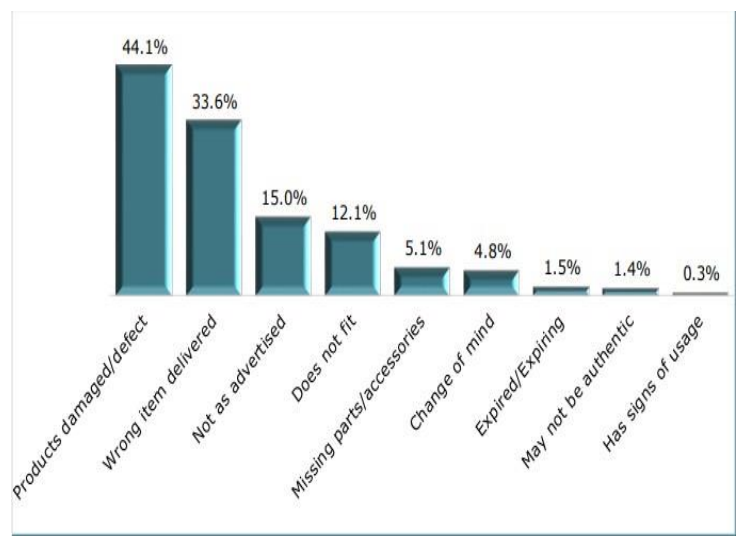

Source: (MCMC, 2018)

Figure 1.1 shows the items returned to Malaysian shoppers for various reasons. The result revealed that product failure is certainly one of the most common causes, with 44.1 percent of online shoppers reporting that after receipt the goods are defective or defect. Another explanation given is that you obtain the wrong item (33.6 percent). When asked about issues they experienced while returning the items they bought, nearly six out of ten (58.3 percent) indicated that they had faced numerous problems in the process. Longer refund or product replacement time tends to be on top of the list (54.1 percent) while 48.8 percent of shoppers cited the obligation to pay the return shipping fee.

\section{Problem Statement}

Based on previous study it is important to study the quality of products and e-services quality that affect customer satisfaction in order to better understand which viewpoint should be used to meet consumer demand, reduce the number of complaints received, and avoid losing business opportunities. Kumar \& Velmurugan (2017) ushered up the biggest challenge when buying products online is the inability to guarantee the quality of the goods. Reviews are not always accurate, and all tests cannot guarantee the quality of products. Dishonest sellers who deliberately deceive consumers to maximize sales are the main reason for selling defective or inferior goods
The brand image is essential not only for a company's long-term competitive advantage, but also for its customer satisfaction when influenced by consumer affection for the quality of service (Ramadhan \& Muthohar, 2019). It shows that brand image has a positive relation to the quality of service and to satisfaction of customers. This study aims to investigate the effect of product quality, e-service quality and brand image towards customer satisfaction among online shopping in Perlis.

online.

Due to the large number of goods handled by ecommerce companies today, it is very difficult to check the quality of each item they sell. Due to fraudulent sellers focusing on sales, some defective products were sold online (Kumar \& Velmurugan, 2017).

Furthermore, according to Zeithaml et al., (2002), the e-services model is defined as an instrument for searching, buying and distributing products and services on the website to be efficient and safe. The conceptualisation of service quality is embedded in the premise of the theory of deconfirmation and the measurement of service quality derives from the contrast between the illusion that the company gives and what it can deliver (Ahmed, 2018).

Main challenge for companies operating in electronic commerce (EC) systems is customer satisfaction. The primary factor determining whether the companies will survive or fail is good quality of service (Okal, 2018). Many companies have to create websites that provide quality information and services to the customers in order to meet their customer requirements. Online service providers should find out which characteristics are used to evaluate overall quality and satisfaction of services and which characteristics are more important (Saha \& Zhao, 2005).

Chinomona et al., (2014) viewed that online consumers typically expect a level of service quality equal to or greater than conventional consumers on channel. A variety of considerations predict the customer 's understanding of the e-services. At the meantime, Lee \& Lin (2005) have identified major factors affecting the customer satisfaction of the quality of e-services in the shopping of online companies, namely, the degree of usability, trustworthiness and security. Munthiu et al. (2014) recommended quality service providers, as this is an advantageous competitive source.

However, Hagos (2012) claimed that customer satisfaction is not enough by itself to build loyal 
customers for any organization. Most of the customers that switched to another company were either unsatisfied or very satisfied with the product or service they first consumed and left. Therefore, this shows that customers will not only be loyal by delivering them good quality service. To support this, Polyakova \& Mirza (2015) references suggested that customers would usually rely on extrinsic signs such as brand image to determine and recognize the quality of service. So if the company has a strong brand image, it is important for its customers.

Moreover, the present market climate aims to encourage new competing companies and competitiveness. The service encourages customers in the alternative community to choose different products or services (Nilsson \& Ballantyne, 2014). It is also important that companies strive to differentiate their offerings from their rivals. The brand image is very essential to attract new customers and to maintain customer satisfaction for every company, because buyers are still looking for branded goods or services in this modern, dynamic environment.

Looking from above mentioned issues, there are not enough research which has been conducting to measure the effect of product quality, e-service quality and brand image towards customer satisfaction. The majority of research is to examine the overall factors that influence the satisfaction of customers in online shopping. They only cover different dimensions of factors such as customer value, service quality, price and security to measure the customer satisfaction. The limited number of studies in Malaysia which tried to explore on the effect product quality, e-service quality, and brand image towards customer satisfaction among online shopping shows a critical gap in the body of existing knowledge.

\section{Research Questions}

1. Is there any significant influence between product quality and customer satisfaction among online shopping in Perlis?

2. Is there any significant influence between eservice quality and customer satisfaction among online shopping in Perlis?

3. Is there any significant influence between brand image and customer satisfaction among online shopping in Perlis?

\section{LITERATURE REVIEW Customer Satisfaction (CS)}

CS is described in the marketing literature as one of the mechanisms that has been most tested. In the competitive climate, this plays an important role as it can maintain existing customers and attract new ones (Deyalage \& Kulathunga, 2019). Keller (2007) defined satisfaction as 'the sense of pleasure or dissatisfaction in an individual arising from a comparison of the results and expectations of the product or service. Yüksel \& Yüksel (2008) gave another point of view in which he described CS as the "market answer to fulfilment." It is a product or service feature decision, or the product or service has actually given a pleasurable level of consumptionrelated fulfilment.

According to Dynamics et al., (2014), CS is usually seen as a result of comparing consumption expectations with experience and CS is achieved when the final deliverable fulfils or exceeds a consumer's expectations. Satisfaction and loyalty are key elements which determine successful market concept implementation (Khristianto et al., 2012). Satisfied customers would most likely plan to buy back if the service provider has met their expectations or surpassed those (Alam \& Yasin, 2010).

Identifying CS variables is important as it acts as a benchmark for business success and also serves as guidance for potential progress (Alam \& Yasin, 2010). Some models about customer satisfaction have been developed earlier. These models were more focused on product and services satisfaction that must be purchased online. Guo et al., (2012) established eight customer satisfaction determinants, namely website design, security, brand image, price, product quality, service quality, variety of products and distribution systems.

Al Karim (2013) developed a model in which the two main reasons for influencing online shopping are the motivations and inhibitions. In this study, the previous researcher found that 90 percent of their respondents considered online shopping to be comfortable, simple, less hassle and time saving. Though flaws in delivery systems, electronic payment processes, product quality and personal consumer services were the key concerns surrounding online shopping, which were seen as inhibiting online shopping. All this explanation will impact CS with online shopping.

Furthermore, Yulisetiarini \& Prahasta (2019) has been conducted East Java Indonesia the effect of price, service quality, customer value, and brand image on CS of Telecommunications company. The research findings show the significant positive impact of all IVs, such as price, service quality and brand images, on CS. The research explain quality of service given should respond quickly with a customer care approach to the needs and expectations of customers as well as customer 
feedback, criticism, suggestions, or just asking for support. Also, it can be said that the brand image of the telecommunications company is strong wellknown, easy to remember, and able to generate customer interest in the products offered.

Nittala (2015) explains factors affecting CS among online shopping in India in their ressearch. Previous researchers have identified 8 factors that are social influence, service quality, promotion, positive attitude, perceived utility, product risk, perceived risk and traditional shopping. There are three factors that have no major effect on the behavior which are promotion and perceived utility of online shopping and traditional shopping. The study found that perceived risk and service quality have had a positive influence on the behaviour of online shopping. Results also indicated that the online shopping behaviour is negatively affected by positive attitude, product risk and financial risk.

Ahmed Nasser. M et al., (2012) explains factors affecting CS of Mobile Services in Yemen. The research analyzed the relationship with CS between perceived quality, perceived value, consumer expectations, and corporate image. The research found that the relationship between perceived quality, perceived value, and brand image has a strong positive impact on CS, while consumer expectation is positive but without statistical significance.

\section{Product Quality (PQ)}

Handoko (2016) stated that PQ is the features of a product or service that depend on its ability to meet actual or implied customer needs. Ziaullah et al. (2014) defined PQ as the actual functionality of the product, consistency between the specification of online shop quality and the true quality of the physical product. The PQ assessment components used in this review are product quality, product selection, and product availability.

Gaurav Akrani (2013) highlighted there are five main elements of PQ. The first element relates to design quality. This is really important as it will affect CS directly. For example, good website design can give their consumer a good first impression (Brevity, 2017). It is therefore very necessary to have a product quality that suits the needs of the customer and also gives a good quality level (Gaurav Akrani, 2013).

Based on the research by Gaurav Akrani (2013), the second element is conformance to quality. This implies that the final product will conform to the specification of the component it produces. Failure to do so would impact its CS as the company did not fulfill its standards.
The third element is reliability. That ensures that the outcome is secure or trustworthy and that there is no easy errors that are always fixed. The business wants to stay operating and will hold it in service for a long time span (Gaurav Akrani, 2013). Not only is efficiency crucial in businesses, it will improve profitability, customer support and overall CS (The Wire, 2017).

The fourth element concerns safety. This ensures that the manufacturer must guarantee that the final goods are healthy to purchase or sell and must check that they will not affect the customer in any manner (Gaurav Akrani, 2013). Safety is important, particularly in the food industry. There is increasing concern for food safety among customers. Consequently, safety is now becoming highly important.

Finally, proper storage is the last element. This ensures that the product must be well-packed and processed. PQ shall be kept until the date of the product expiry (Gaurav Akrani, 2013).

By having PQ, it may lead to maintaining CS and loyalty. It would the the probability and expenses of removing the incorrect product that workers generate at the same period (Lan Linton, 2018). In addition to the importance of PQ for the company, the customer is important as well. This is because customers have a high price that suits the amount they have invested and want to have the highest quality products in place. The rivals would demand if the company does not. A number of high-quality foreign products were now sold on the local market. Thereby, local companies may not be able to survive on the market unless they raise their PQ to a higher level (Gaurav Akrani, 2013).

For the online shopping, PQ is also important. According to the Product Details Report, the quality of the product has become one of the main success drivers in online transactions (Retail Dive, 2016). Product is all that can be sold on the market to gain the interest of customers, industry demand, use or use that can meet customer needs (Suhendar \& Ruswanti, 2019). Therefore, PQ is great value to the customer because they can fulfill when the expected satisfies their standards while not meeting when the service slips behind their standards (Khan \& Alshare, 2015).

\section{E-Service Quality (SQ)}

Kortunay (2016) refers to SQ as 'the degree to which a website permits the safe and productive procurement, development and transmission of products and services.' Lu \& Yuwen Shiu (2009), if the perceived interest and customer motivation would be influenced by the standard of service, were 
analyzed. Based on the results of the analysis, they noticed that the perception of SQ more influenced customers than the quality of the product, particularly during the service encounter process.

In addition, Zehir \& Narcikara (2016) described the SQ as a standard of e-service distribution the assesses the general consumer's virtual marketplace. Many studies examine how the quality of service will influence consumer decision in recent decades. However, further surveys are now being carried out, because the customer understands more about ecommerce. For example, many individuals will assess the efficacy of virtual community websites (Koirala \& Shrestha, 2012).

Previous study by Xu (2017), several researchers have developed WebQual to measure 12 dimensions of websites. All twelve dimensions are customized material, dedication, trust, time for response, reaction, visual appeal, creativity, movement, emotional appeal, collaborative connectivity, market processes and the capacity to substitute. SQ has been one of the key considerations for customers to allow them to select an online retailer (Lee \& Lin, 2005).

Shahid et al., (2019) views SQ as an assessment of the service's standard or distinction. Mmutle \& Shonhe (2017) also described the quality of service as a contrast between the service expectations they would receive for the price they paid with the service they actually provided and measured. Kim (2010) stated that in order to achieve excellence and survive in a competition, all business entities should make efforts to increase the SQ which will have a positive impact on CS. Thus, Kursunluoglu Yarimoglu (2015) concluded The higher the SQ level, the higher the CS efficiency.

In addition, Marković \& Janković (2013) also highlighted SQ's contribution to the satisfaction of hotel guests in Malaysia given the fact that measurable development appears to be CS's most important factor. Izogo \& Ogba (2015) has also mentioned that as long as the service offered meets the consumer's needs, customers would be satisfied with the service. It also has become a requirement for companies wishing to please their customers to comply with the quality of service offered by their customers. It is necessary, to satisfy customers more than unsatisfied customers engage in the business.

Based on the research by Hussain, Al Nasser, \& Hussain's (2015), a declaration on the value of improving SQ relies on the flight companies' willingness to fulfill the organisation and its CS in the airline industry. The company can gain monetary benefit and competitive advantage by making sure CS maximizes its capabilities to generate and maintain SQ. SQ also becoming a superiority which meets the demand of the consumer. Hence, having a good e-service quality is important to increase CS (Rasli et al., 2018).

\section{Brand Image (BI)}

Ebrahim et al. (2016) defined BI as the perception that the public can remember about a particular brand. Lahap et al., (2016) explained the BI as certain product or service characteristics that had remained in the mind of the customer. When consumers consider a brand name, they instinctively think about the qualities about their product or service with a single phrase. Kandampully \& Suhartanto (2000) stated that the BI is relevant in companies because it impacts consumers' view of products and services and affects the judgment and actions of the customer.

A business with a favorable image would definitely gain a better market position (Jr et al., 2007). Measuring brand image is therefore an important part, as it would help marketers identify the perceptions of customers regarding their product or service. The favorable mass-market BI is very critical to improve the company's market share. Furthermore, Koo (2003) added that the BI is useful for improving consumer engagement, brand value , brand efficiency, and purchasing habits. The reputable BI allows customers to distinguish their brand needs, differentiating the company from others, and enhancing CS across the brand (Hess and Story, 2006).

Lahap et al., (2016) was determined a study on BI towards CS in the Malaysian Hotel Industry. The result was found to be interesting and revealed that BI has a strong relationship with $\mathrm{CS}$ in the Malaysian hotel industry context. Thus, this study is important as it enhances further the perception of what consumers actually want when choosing a hotel. Therefore, this study has the capacity to offer hotel operators a way to plan, formulate, and decide to what extent they should improve their brand image to compete in the long run. Two of the key variables influencing consumer buying behaviour is the feeling of customers (Berry, 2000). Research by Jr et al. (2007) reported that brand success will create recognition of the brand's reputation among consumers and thereby maximize the company's competitiveness by buying the company's goods and services. 


\section{CONCEPTUAL FRAMEWORK}

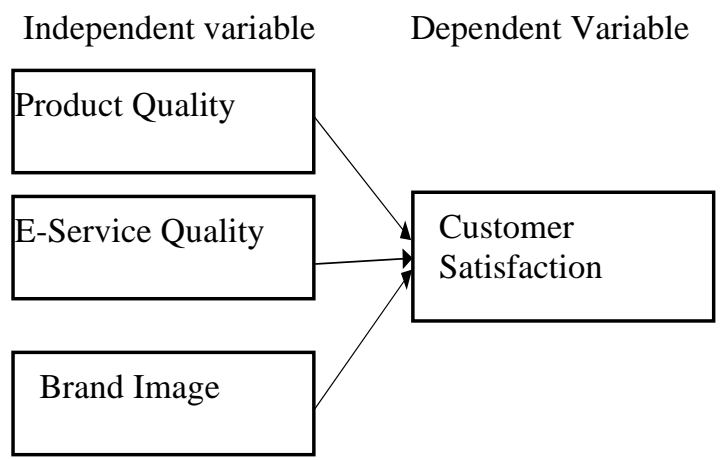

Based on literature review, a study of the relationship between $\mathrm{PQ}, \mathrm{SQ}, \mathrm{BI}$ and $\mathrm{CS}$ and related hypothesis has been conducted from the above conceptual framework.

Relationship between product quality and customer satisfaction

The quality of an organization that can affect the performance, sustainability, and longevity of the organization is crucial. (Athiyah, 2016). Quality is rewarding, thus satisfaction is loyal and eventually loyalty contributes to profits. Therefore, the interaction between $\mathrm{PQ}$ and $\mathrm{CS}$ is of positive importance (Athiyah, 2016). Additionally, several studies provided strong empirical support about PQ was being an antecedent, with a positive relationship to overall CS. Study of Hilman \& Hanaysha (2015) claimed that high PQ always to CS that further engenders loyalty.

Wantara \& Tambrin (2019) mentioned that the relationship between CS and PQ is positive and significant. Where the product's perceived quality exceeds standards, the customer will be satisfied and will find it a good quality. Better PQ will maintain our high level of CS, which encourages customers to make future purchases (Wantara \& Tambrin, 2019). Jahanshahi et al., 2011 identified highest quality standards to satisfy the needs of its customers. Therefore, it is clearly to show that between PQ and $\mathrm{CS}$, there is a positive significance.

H1: Product Quality is positive impact of customer satisfaction

Relationship between e-service quality and customer satisfaction

According to Lee \& Lin (2005), SQ was defined as an overall performance measurement and appraisal for e-service efficiency on the virtual sector. Kristianto et al. (2012) state that the standard of service is what was supposed to be satisfactory and satisfactory in meeting the demand of the customers. Getting an overall good standard of SQ is therefore critical for that CS. Guo et al., ( 2012) defined SQ as the standard of support for the delivery of secure and rentable shopping, buying and distribution of products and service by online retailers.

Similarly to Zehir \& Narcikara (2016) noted that customer satisfaction and the importance of the shopping experience will be improved most definitely by the online retailers willing to access and share knowledge through a formal or informal forum. Ludin \& Cheng (2014) study reveals that in online shopping there is a connection between SQ and CS. The findings indicate that Chang et al. (2009) and even Luo, Ba and Zhang (2012) are constant in the researched model. SQ will improve CS . Furthermore, Libai et al., (2010) reported that online dealers offer various modes of communication to their consumers to improve consumer to consumer ties $(\mathrm{C} 2 \mathrm{C})$. The different messaging networks have the adaptability and flexibility to satisfy the customer's needs.

Therefore, these requirements would be put more focus on for an online retailer. In fact, online vendors have to protect both the pre-commercial and the post-commercial phases. This may add to CS development by boosting SQ (Ludin \& Cheng, 2014).

\section{H2: E-Service Quality is positive impact of customer} satisfaction

\section{Relationship between brand image and customer satisfaction}

From the concept of brand, it is generally believed that a good BI will have a positive impact on CS. Therefore, a good supermarket BI will tend to generate high CS in the store. Lahap et al. ( 2016) believed BI has a good association with CS. They also added that the variations in customer loyalty are clearly shown by CS and BI and organizational efficiency. Nyadzayo \& Khajehzadeh (2016) found that consumer perception of a BI has increased, CS will increase. This perception is the consumer's 
positive perception of a good company business, which increases consumer confidence in the brand to achieve a certain level of satisfaction. Based on researchers', BI position is very significant, because it is a tool for enticing customers when a product's $\mathrm{BI}$ is considered fine.

BI as a way of evaluating the extent of customer awareness of services rendered is used by the business. Huang et al., (2016) has demonstrated that $\mathrm{BI}$ has beneficial impacts on the level of service and CS in the karaoke TV industry. Rahi \& Abd Ghani (2017) has culminated in a major positive impact on consumer loyalty with CS and BI. Nyambane \& Ezekiel (2013) found that BI indirectly affects loyalty through CS. Moreover, BI may have a direct or indirect impact on loyalty.

However, BI can definitely be regarded as a predictor of customer loyalty. It is acknowledged that a positive BI helps increase CS. As a result, BI is critical to a company's lifetime CS, which increases organizational efficiency.

\section{H3: Brand Image is positive impact of customer satisfaction}

\section{RESEARCH DESIGN AND FINDINGS}

The research design is the most critical step in ensuring that the study is performed effectively and at the same time consistently attaining the purposes and objectives. This research applies quantitative methods which are used to collect the data using questionnaires. The aim of the study was to evaluate the effect of PQ, SQ and BI towards CS among online shopping in Perlis.

\section{Data Collection}

There are two types which are primary data collection which is collected through questionnaire distribution and secondary data collection which is collected through data collection system interviews. For this study the primary method of gathering data will be used.

\section{Population and Sampling}

Population can be described by a collection of features used by statisticians to draw conclusions about research topics. The sample is a random set of inhabitants. This is a smaller population-drawn group which has the features of the larger population. The population is given the findings and conclusions of the sample data.

Krejcie \& Morgan (1970) proposed a table for a broad population, using a procedure for simplifying the process of sample size estimates for a limited population. Based on the table, the sample size in this have reached the reported maximum population size. Therefore, researchers are choosing analysis is 340 respondents. It's because Perlis' total population is around 254,400 people who maximum sample size, 340 respondents, to make this study more reliable.

\section{Sampling Technique}

The probability sampling technique and nonprobability sampling technique is the method in the data collection. In this research, the researcher believes that the probability sampling technique is a better fit for its population. In this study, random sampling technique was chosen as sampling technique under probability sampling technique. Probability sampling is more accurate and effective than a non-probability sampling methodology, as it represents the features of the entire community and is able to interpret sample outcomes.

\section{Unit of Analysis}

The unit of analysis for this study is the individual online consumers in Perlis. Any research needs to decide the unit of study, so that researchers can recognize the research's problems. Therefore, researchers have been conducting research on the online shopping users in Perlis for purposes to identify the effect PQ, SQ and BI towards CS.

\section{DATA ANALYSIS}

Statistical Analysis refers to the process of gathering large amounts of the data and recording overall trends. Statistical Analysis is an important part of data processing. It will contain a constant pattern and summarize the correct information revealed on the analysis. In this thesis the researcher used statistical software computerization which is the Statistical Package for the Social Sciences (SPSS). SPSS is a package of predictive data analyzer tools. It is used for rigorous statistical analysis by different researchers. The statistical used to measure the strength of a linear relationship between the independent variable and dependent variable is the correlation coefficient.

\section{Reliability Analysis}

Cronbach's Alpha Coefficient is the most common measure for reliability of inter- item consistency. The Cronbach's Alpha is used to calculate the reliability of the instruments in the analysis and between two scores ranging from 0 to 1.00, the most common type of internal accuracy reliability coefficient. The higher alpha coefficient value which is equal to 1 has better reliability and the minimum value of the alpha coefficient value to be accepted as reliability is 0.6 , any value below 0.6 
Lee Sze Yuan et al. / International Journal of Business and Management, 4(5) 2020, Pages: 43-54

would be unacceptable (Mahlangu \& Kruger, (2015).

\section{Pearson Correlation Coefficient}

The correlation coefficient of Pearson is a bi-variate analysis that calculates the interaction intensity between two variables and the direction of the relationship. The value of the correlation coefficient ranges between +1 and -1 in relation to the intensity of the relation. A value of \pm 1 indicates a complete degree of correlation between the two variables.

Table 1: Pearson Correlation Coefficient

\begin{tabular}{|l|l|l|l|l|l|}
\hline & & IV1 & IV2 & IV3 & DV \\
\hline IV1 & $\begin{array}{l}\text { Pearson } \\
\text { Correlation }\end{array}$ & 1 & $.830^{* *}$ & $.834^{* *}$ & $.792^{* *}$ \\
\hline & Sig. (2-tailed) & & .000 & .000 & .000 \\
\hline & $\mathrm{N}$ & 250 & 250 & 250 & 250 \\
\hline IV2 & $\begin{array}{l}\text { Pearson } \\
\text { Correlation }\end{array}$ & $.830^{* *}$ & 1 & $.864^{* *}$ & $.796^{* *}$ \\
\hline & Sig. (2-tailed) & .000 & & .000 & .000 \\
\hline & $\mathrm{N}$ & 250 & 250 & 250 & 250 \\
\hline IV3 & $\begin{array}{l}\text { Pearson } \\
\text { Correlation }\end{array}$ & $.834^{* *}$ & $.864^{* *}$ & 1 & $.853^{* *}$ \\
\hline & Sig. (2-tailed) & .000 & .000 & & .000 \\
\hline & $\mathrm{N}$ & 250 & 250 & 250 & 250 \\
\hline DV & $\begin{array}{l}\text { Pearson } \\
\text { Correlation }\end{array}$ & $.792^{* *}$ & $.796^{* *}$ & $.853^{* *}$ & 1 \\
\hline & Sig. (2-tailed) & .000 & .000 & .000 & \\
\hline & $\mathrm{N}$ & 250 & 250 & 250 & 250 \\
\hline
\end{tabular}

Table 1, shows the relationship between the three IV which are PQ, SQ, BI and DV is Customer Satisfaction. The first correlation is between Product Quality and Customer Satisfaction, from the results, it shows that $r$-value is 0.792 or $79.2 \%$, this figure represents a very strong relationship. Next, the second correlation is between the E-Service Quality and Customer Satisfaction, based on table 4.4, the result shows that r-value is 0.796 or $79.6 \%$, this figure also represents a very strong relationship. The third also last correlation is between Brand Image and Customer Satisfaction, the result shows that $\mathrm{r}-$ value is 0.853 and $85.3 \%$, it also represents a very strong relationship between DV and IV.

\section{Multiple Regression Analysis}

Multiple regression analysis is a method used to predict a variable's uncertain value using the estimated value of two variables or even more. Multiple linear regressions could be formed when consisting of one DV and more than one IV. Multiple regression analysis has the purpose of evaluating the relationship between the DV and IV. Using linear regression modeling, all of the variables were analyzed. The details shall be showed in the table below.

Table 2: Multiple Regression Analysis

\begin{tabular}{c|c|c|c|c}
\hline Model & $\mathrm{R}$ & R Square & $\begin{array}{c}\text { Adjusted } \\
\text { R Square }\end{array}$ & $\begin{array}{c}\text { Std. Error } \\
\text { of the } \\
\text { Estimate }\end{array}$ \\
\hline 1 & $.868^{\mathrm{a}}$ & .753 & .750 & .24754 \\
\hline
\end{tabular}

a. Predictors: (Constant), IV3, IV1, IV2

As shown in Table 2 the value of $\mathrm{R}$ Square is 0.753 which mean about $75.3 \%$ of the variation in the DV, Customer Satisfaction is explained by those IV which are Product Quality, E-Service Quality and
Brand Image. The adjusted R Square indicates how well the model generalizes. While the adjusted value for R Square is 0.750 or $75 \%$ and it is very close to 
the $\mathrm{R}$ Square. Therefore, it indicates the model generalizes well for the population.

$\mathrm{F}$ ratio is used to assess the overall fitness of the regression model. The F-value is 250.575 and it is get from Mean Square Regression, 15.354 after divided by the Mean Square Residual, 0.061 (please refer to appendix 1). According to Appendix 1, the probability shown as "Sig" is 0.000 , so it is meant that the overall regression model is significant, indicating the three IV has worked well in explaining the variation in the DV.

On the other hand, the effectiveness of each IV in affecting the DV is determined by the standard coefficient beta value (please refer to appendix 2). From Appendix 2, it is found that the standard coefficient (Beta) is 0.213 for Product Quality, 0.142 for E-Service Quality and 0.553 for Brand Image.

The significant level of Product Quality is 0.001 . The test result shows the coefficient of the independent variable is statically significant not more than 0.05. Therefore, the hypothesis of Product Quality is accepted. The significant level of EService Quality is 0.039 . The test result shows the coefficient of the independent variable is not more than 0.05. Therefore, the hypothesis of E-Service Quality is accepted. The significant level of Brand Image is 0.000 . The test result shows the coefficient of the independent variable is statistically significant not more than 0.05 . Therefore, the hypothesis of Brand Image is accepted.

\section{DISCUSSIONS}

Does the product quality of online shopping have impact on customer satisfaction?

The finding in this research showed that the relationship between PQ and CS is significant where the level significant is 0.001 which is lower than 0.05 . Hence, the result of hypothesis is accepted. A analysis of customer preferences shows that PQ is one of three factors that can be examined which influence changes in online CS (Deyalage \& Kulathunga, 2019). Performance is the intrinsic quality of a company and the desired level of performance in a good or service according to the design variables (Christian \& France, 2015). Improving PQ is going to have a beneficial impact on CS development (Jiradilok et al., 2014). Besides that, Luo, Ba and Zhang's study (2012) supports this observation. The research carried out on eight determinants and proved once again the product quality and website design, reliability, knowledge quality, payment process, quality of electronic service, product variety and service delivery.
Does the e-service quality of online shopping have impact on customer satisfaction?

The finding indicated that SQ and CS were positively related. The level significant showed 0.039 which lower than 0.05 , the result of hypothesis is accepted. The finding was comparable with the outcome of retail distribution, discounts, refund policy and quality of customer support would impact the satisfaction of customers online (Momotaz \& Hasan, 2018). At the same period, SQ was sponsored and knowledge quality was two variables that influenced CS (Kumar \& Velmurugan, 2017). The result for SQ and CS also builds in line with Luo, Ba and Zhang (2012) research. The researchers said SQ would help improve customer trust and CS, as sellers are not very noticeable (Luo, Ba and Zhang, 2012).

\section{Does the brand image of online shopping have impact on customer satisfaction?}

The finding indicated that BI and CS were positively correlated. The level significant showed 0.000 which lower than 0.05 , the result of hypothesis is accepted. These findings indicate several observational research, which conclude that a BI would lead to CS (Neupane, 2015), and purchase behavior (Jr et al., 2007). In addition, (Neupane, 2015) added that BI is useful for improving loyalty, brand equity, brand performance and CS. These findings are further consistent with the results obtained by Cretu \& Brodie (2007). However, in this sense, BI expresses the consumer's belief that the brand will continue to satisfy its experienced brand satisfaction (Chinomona, 2013). Therefore, the higher the customer's brand satisfaction, the higher the brands trust.

\section{REFERENCES}

[1] Ahmed, M. (2018). Service Quality in Accounting Firms: its Effect on Client Satisfaction and Loyalty.

[2] Ahmed Nasser. M, H., Bt Md. Salleh, S., \& Mahmood Gelaidan, H. (2012). Factors Affecting Customer Satisfaction of Mobile Services in Yemen. American Journal of Economics, 2(7), 171-184. https://doi.org/10.5923/j.economics.20120207 .03

[3] Al-Jahwari, N. S., Khan, M. F. R., Al Kalbani, G. K., \& Al Khansouri, S. S. (2018). Factors influencing customer satisfaction of online shopping in Oman - Youth perspective. Humanities and Social Sciences Reviews, 6(2), 64-73. https://doi.org/10.18510/hssr.2018.628

[4] Al Karim, R. (2013). Customer Satisfaction in Online Shopping: a study into the reasons for motivations and inhibitions. IOSR Journal of 
Business and Management, 11(6), 13-20. https://doi.org/10.9790/487x-1161320

[5] Alam, S. S., \& Yasin, N. M. (2010). An Investigation into the Antecedents of Customer Satisfaction of Online Shopping. Journal of Marketing Development and Competitiveness, 5(1), 71-78.

[6] Chinomona, R. (2013). The Influence Of Brand Experience On Brand Satisfaction, Trust And Attachment In South Africa. International Business \& Economics Research Journal (IBER), 12(10), 1303. https://doi.org/10.19030/iber.v12i10.8138

[7] Chinomona, R., Masinge, G., \& Sandada, M. (2014). The influence of E-service quality on customer perceived value, customer satisfaction and loyalty in South Africa. Mediterranean Journal of Social Sciences,5(9), 331-341. https://doi.org/10.5901/mjss.2014.v5n9p331

[8] Cretu, A. E., \& Brodie, R. J. (2007). The influence of brand image and company reputation where manufacturers market to small firms: A customer value perspective. Industrial Marketing Management, 36(2), 230240.

https://doi.org/10.1016/j.indmarman.2005.08. 013

[9] Deyalage, P. A., \& Kulathunga, D. (2019). Factors Affecting Online Customer Satisfaction: The Sri Lankan Perspective. International Journal of Business and Management, $\quad$ 14(2), 99. https://doi.org/10.5539/ijbm.v14n2p99

[10] Dynamics, M., Volume, K. E., Books, T., Bt, I. H., Ludin, H., \& Cheng, B. L. (2014). Factors Influencing Customer Satisfaction and ELoyalty: Online Shopping Environment among the Young Adults. Management Dynamics in the Knowledge Economy, 2(3), 462-471.

[11] Ebrahim, R., Ghoneim, A., Irani, Z., \& Fan, Y. (2016). A brand preference and repurchase intention model: the role of consumer experience. Journal of Marketing Management, 32(13-14), 1230-1259. https://doi.org/10.1080/0267257X.2016.1150 322

[12] Guo, X., Ling, K. C., \& Liu, M. (2012). Evaluating factors influencing consumer satisfaction towards online shopping in China. Asian Social Science, 8(13), 40-49. https://doi.org/10.5539/ass.v8n13p40

[13] Hagos, S. (2012). The effect of brand image on customer brand loyalty. Бюллетень Результатов Научных Исследований, 4 (3).

[14] Handoko, L. P. (2016). the Effect of Product Quality and Delivery Service on OnlineCustomer Satisfaction in Zalora Indonesia. Jurnal Riset Ekonomi, Manajemen, Bisnis Dan
Akuntansi, 4(1), 1189-1199. https://doi.org/10.35794/emba.v4i1.11876

[15] Hilman, H., \& Hanaysha, J. (2015). The impact of advertising on relationship quality: Empirical evidence from Malaysia. Research Journal of Applied Sciences, Engineering and Technology, 10(3), 253-261. https://doi.org/10.19026/rjaset.10.2485

[16] Hoe, L. C., \& Mansori, S. (2018). The Effects of Product Quality on Customer Satisfaction and Loyalty: Evidence from Malaysian Engineering Industry. International Journal of Industrial Marketing, 3(1), 20. https://doi.org/10.5296/ijim.v3i1.13959

[17] Huang, Y., Hong, J., \& Chang, H. H. (2016). The impact of power on reliance on feelings versus reasons in decision making. In Advances in Consumer Research (Vol. 44).

[18] Jiradilok, T., Malisuwan, S., Madan, N., \& Sivaraks, J. (2014). The Impact of Customer Satisfaction on Online Purchasing: A Case Study Analysis in Thailand. Journal of Economics, Business and Management, 2(1), 5-11. https://doi.org/10.7763/joebm.2014.v2.89

[19] Journal, G., Science, C., Classification, G., Khawaja, K. F., \& Bokhari, R. H. (2010). Exploring the factors associated with quality of website. Global Journal of Computer Science and Technology, 10(14), 37-45.

[20] Jr, S. L. S., Omar, M. W., \& Wahid, N. A. (2007). the Effect of Brand Image on Overall Satisfaction and Loyalty Intention in the Context of Color Cosmetic. Asian Academy of Management Journal, 12(1), 83-107.

[21] Kandampully, J., \& Suhartanto, D. (2000). Customer loyalty in the hotel industry: The role of customer satisfaction and image. International Journal of Contemporary Hospitality Management, 12(6), 346-351. https://doi.org/10.1108/09596110010342559

[22] Keller, K. L. (2007). Marketing Management 12. vydání . March, 1-5. http://books.google.cz/books?id=pkWsyjLsfG $\mathrm{gC}$

[23] Koirala, K. D., \& Shrestha, S. K. (2012). Measuring Service Quality and Customer Satisfaction: Empirical Evidence from Nepalese Commercial Banking Sector Undertakings. Management Dynamics, 16(1), $1-13$.

[24] Kortunay, N. (2016). Measuring Internet Service Quality Of E-Commerce Web Sites By Using E-S-Qual In Turkey. European Scientific Journal, 7881(August), 390-401.

[25] Kumar, M., \& Velmurugan, R. (2017). Customer satisfaction towards online shopping in Coimbatore district. International Journal of Pure and Applied Mathematics, 15, 41-49. 
[26] Kursunluoglu Yarimoglu, E. (2015). A Review of Service and E-Service Quality Measurements: Previous Literature and Extension. Journal of Economic and Social Studies, $\quad 5(1)$, 169-200. https://doi.org/10.14706/jecoss 115110

[27] Lahap, J., Ramli, N. S., Said, N. M., Radzi, S. M., \& Zain, R. A. (2016a). A Study of Brand Image towards Customer's Satisfaction in the Malaysian Hotel Industry. Procedia - Social and Behavioral Sciences, 224(August 2015), 149-157. https://doi.org/10.1016/j.sbspro.2016.05.430

[28] Lahap, J., Ramli, N. S., Said, N. M., Radzi, S. M., \& Zain, R. A. (2016b). A Study of Brand Image towards Customer's Satisfaction in the Malaysian Hotel Industry. Procedia - Social and Behavioral Sciences, 224(June), 149-157. https://doi.org/10.1016/j.sbspro.2016.05.430

[29] Lee, G. G., \& Lin, H. F. (2005). Customer perceptions of e-service quality in online shopping. International Journal of Retail and Distribution Management, 33(2), 161- 176. https://doi.org/10.1108/09590550510581485

[30] Libai, B., Bolton, R., Bügel, M. S., de Ruyter, K., Götz, O., Risselada, H., \& Step hen, A.

[31] T. (2010). Customer-to-customer interactions: Broadening the scope of word of mouth research. Journal of Service Research, 13(3), 267-282. https://doi.org/10.1177/1094670510375600

[32] Lim, Y. S., Heng, P. C., Ng, T. H., \& Cheah, C. S. (2016). Customers' online website satisfaction in online apparel purchase: A study of Generation Y in Malaysia. Asia Pacific Management Review, 21(2), 74-78. https://doi.org/10.1016/j.apmrv.2015.10.002

[33] Lin, C. C., Wu, H. Y., \& Chang, Y. F. (2011). The critical factors impact on online customer satisfaction. Procedia Computer Science, 3, 276-281. https://doi.org/10.1016/j.procs.2010.12.047

[34] Lu, I., \& Yuwen Shiu, J. (2009). Customers' Behavioral Intentions in the Service Industry: An Empirical Study of Taiwan Spa Hotels. Asian Journal on Quality, 10(3), 73-85. https://doi.org/10.1108/15982680911021205

[35] Malik, M. E., Naeem, B., \& Munawar, M. (2012). Brand Image: Past, Present and Future Muhammad. Journal of Basic and Applied Scientific Research, 2(12), 13069-13075.

[36] Marković, S., \& Janković, S. R. (2013). Exploring the relationship between service quality and customer satisfaction in croatian hotel industry. Tourism and Hospitality Management, 19(2), 149-164.

[37] Mathan Kumar, V., \& Velmurugan, R. (2017). Customers problems towards online shopping in Coimbatore district. Journal of Advanced
Research in Dynamical and Control Systems, 9(Special Issue 13), 545-548.

[38] MCMC. (2018). E-Commerce Consumers Survey 2018. E-Commerce Consumers Survey 2018, 1-49. http://www.mcmc.gov.my

[39] Mmutle, T., \& Shonhe, L. (2017). Customers' perception of service quality and its impact on reputation in the hospitality industry. African Journal of Hospitality, Tourism and Leisure, 6(3).

[40] Momotaz, S. N., \& Hasan, S. (2018). Exploring the Impact of Service Quality Factors on Customer Satisfaction towards Online Shopping: Evidence from Bangladesh. 8(1), 102-123.

[41] Munthiu, M.-C., Velicu, B. C., Tuţă, M., \& Zara, A. I. (2014). Service Quality Evaluation Models Determined by Online Consumer Perception and Satisfaction. Procedia - Social and Behavioral Sciences, 109, 1303-1308. https://doi.org/10.1016/j.sbspro.2013.12.629

[42] Neupane, R. (2015). The Effects of Brand Image on Customer Satisfaction and Loyalty Intention in Retail Super Market Chain UK. International Journal of Social Sciences and Management, 2(1), 9-26. https://doi.org/10.3126/ijssm.v2i1.11814

[43] Nilsson, E., \& Ballantyne, D. (2014). Reexamining the place of servicescape in marketing: A service-dominant logic perspective. Journal of Services Marketing, 28(5), 374-379. https://doi.org/10.1108/JSM01-2013-0004

[44] Nittala, R. (2015). Factors Influencing Online Shopping Behavior of Urban Consumers in India. International Journal of Online Marketing, 5(1), 38-50. https://doi.org/10.4018/ijom.2015010103

[45] Nyadzayo, M. W., \& Khajehzadeh, S. (2016). The antecedents of customer loyalty: A moderated mediation model of customer relationship management quality and brand image. Journal of Retailing and Consumer Services, 30, 262-270. https://doi.org/10.1016/j.jretconser.2016.02.0 02

[46] Nyambane, M. M., \& Ezekiel, M. M. (2013). The Relationship between Rebranding and Customer Loyalty: The Case of Kenya Power. International Journal of Science and Research, 4(December 2013), 2319-7064. https://doi.org/10.13140/RG.2.1.2030.2325

[47] Okal, J. E. (2018). Assessing Service Quality and Customer Satisfaction Using SERVQUAL Model: An Empirical Study of Palestinian Conventional Banks Assessing Service Quality and Customer Satisfaction Using SERVQUAL Model: An Empirical Study of Palestinian Conventional Banks. 
[48] Polyakova, O., \& Mirza, M. (2015). Perceived service quality models: Are they still relevant? The Marketing Review, 15(1), 5982.https://doi.org/10.1362/146934715x14267 608178721

[49] RAHI, S., \& Abd Ghani, M. (2017). the Influence of E-Customer Services and Perceived Value on Brand Loyalty of Banks and Internet Banking Adoption: a Structural Equation Model (SEM). Journal of Internet Banking and Commerce, 22(1).

[50] Ramadhan, M. D., \& Muthohar, M. (2019). The influence of perceived price, perceived quality, brand image, and store image on the purchase intention of Hypermart private label. 308(Insyma), 140-143. https://doi.org/10.2991/insyma-19.2019.36

[51] Rasli, S., Khairi, N., Khairi2, N., Ayathuray, H., $\&$ Syafiq, M. (2018). The Impact of E-business Website Quality on Customer Satisfaction. December.

https://www.researchgate.net/publication/329 916119

[52] Saha, P., \& Zhao, Y. (2005). Relationship between Online Service Quality and Customer Satisfaction: A Study in Internet Banking. Masters Thesis, 1-107. https://doi.org/10.1016/j.toxlet.2014.01.028

[53] Shahid, R. M., Halim, F., \& Shehzad, A. (2019). www.econstor.eu.

[54] Sobihah, M., Mohamad, M., Ali, N. A. M., \& Wan Ismail, W. Z. (2015). E-commerce service quality on customer satisfaction, belief and loyalty: A proposal. Mediterranean Journal of Social Sciences, 6(2), 260-266. https://doi.org/10.5901/mjss.2015.v6n2p260
[55] Suhendar, U., \& Ruswanti, E. (2019). Effect of Product Quality, Perception of Price and Satisfaction

[59] Yüksel, A., \& Yüksel, F. (20 08). Consumer satisfaction theories: Acritical review. Tourist Satisfaction and Complaining Behavior, 1984, 65-88.

[60] Yulisetiarini, D., \& Prahasta, Y. A. (2019). The effect of price, service quality, customer value, and brand image on customers satisfaction of telkomsel cellular operators in east Java Indonesia. International Journal of Scientific and Technology Research, 8(3), 5-9.

[61] Zehir, C., \& Narcıkara, E. (2016). E-Service Quality and E-Recovery Service Quality: Effects on Value Perceptions and Loyalty Intentions. Procedia - Social and Behavioral Sciences, 229, 427-443. https://doi.org/10.1016/j.sbspro.2016.07.153

[62] Zeithaml, V. A., Parasuraman, A., \& Malhotra, A. (2002). Service quality delivery through web sites: A critical review of extant knowledge. Journal of the Academy of Marketing Science, 30(4), 362-375. https://doi.org/10.1177/009207002236911

[63] Zendehdel, M., Paim, L. H., \& Osman, S. B. (2015). Students' online purchasing behavior in Malaysia: Understanding online shopping attitude. Cogent Business and Management, 2(1). https://doi.org/10.1080/23311975.2015.10784 28

[64] Ziaullah, M., Feng, Y., \& Akhter, S. N. (2014). E-Loyalty: The influence of product quality and delivery services on e-trust and esatisfaction in China. International Journal of Advancements in Research \& Technology, 3(10), 20-31. 